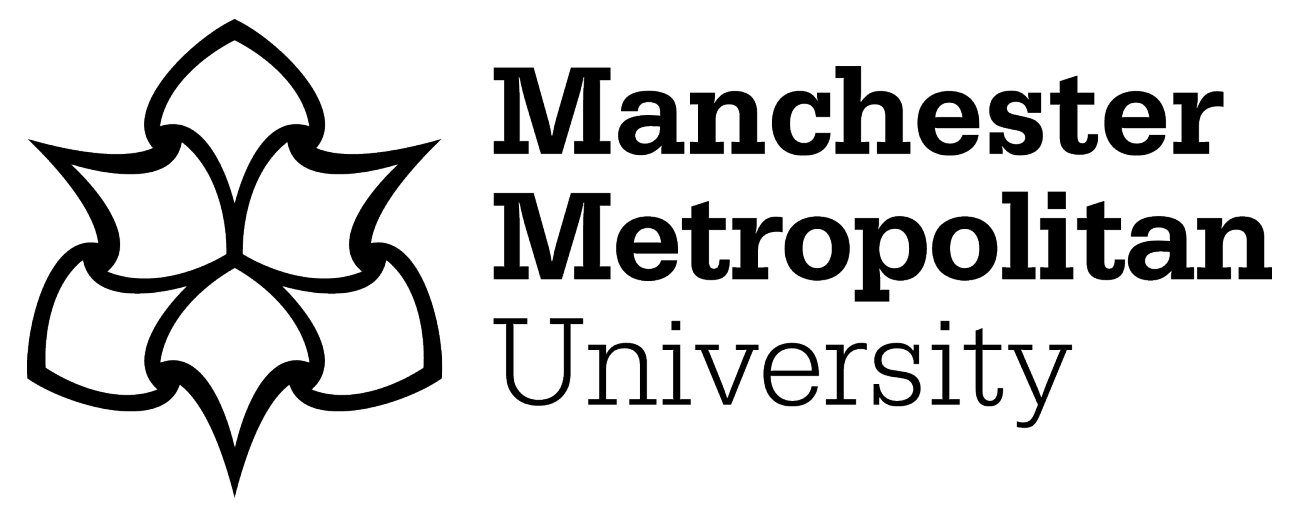

Hawley, S (2019) War Memorial: the Calling Blighty films and remembrance. Media, War and Conflict, 12 (3). pp. 263-280. ISSN 1750-6352

Downloaded from: https://e-space.mmu.ac.uk/618262/

Publisher: SAGE Publications

DOI: https://doi.org/10.1177/1750635218763222

Please cite the published version 


\section{War Memorial; the Calling Blighty films and remembrance}

'The past is not fixed in the way that linear time suggests. We can return. We can pick up what we dropped. We can mend what others broke. We can talk with the dead.' (Jeanette Winterson, Why Be Happy When You Can Be Normal? 2009: 58)

Blighty; an English slang term for Britain, deriving from the Hindustani word vilāyatī ( $\square \square \square \square \square \square \square$ ) meaning "foreign" (Oxford English Dictionary 2017)

Most non-fiction films from World War Two are highly mediated documents; newsreels, battle films or recreations of battles, moving images subject to the framing view of the director, or editor, focusing on action and major events, or the pronouncements of leading actors, presidents and generals. The voice of the ordinary servicemen is significantly absent for the most part from this canon. However the Calling Blighty series (1944-46), filmed messages sent home between 1944 to 1946 from the Far East theatre to be screened to an audience of parents, wives, and sweethearts in regional cinemas, do represent the voice and personality of the ordinary enlisted man (and a very few women) at a time of war, in a largely ostensibly uncensored and direct way.

These films from men of the Fourteenth Army, around 80 hours of them originally, of which 12 hours survive, had a particular meaning and context when produced and screened in cinemas on the home front. However I have, along with Marion Hewitt, director of the North West Film Archive, recreated the screenings of over 70 years ago, which has led to wide media coverage including a Channel 4 documentary, Messages Home: Lost Films of the British Army (2016), plus my own film War Memorial (Hawley 2016) edited from the collection of films that still exist. I suggest that these three media representations of the wartime archive films represent three different modes of collective remembrance, filtered to express the needs and context of differing kinship and wider audiences. These are; ritual ceremony for the recreated screenings for families of the men, media memorial for the TV program, and creative critical reflection for the experimental/artist's film. From my own perspective, not as an historian but an artist/filmmaker who co- instigated the Message Home project, I want to examine the issues surrounding these films and their particular resonance for a contemporary audience of the families and the wider public.

The whole Calling Blighty project, which has so far lasted two years and will continue for some years more, brings families together within particular cities, and binds their individual familial memories into a larger whole, framed by a website where relatives can go to identify their forefathers, and reconnect with their wartime testimony. Photographs of all the men and women from the Manchester, Sheffield and York films - 35 films and 700 individuals- are displayed in a searchable form with as much back up information as possible, and we hope eventually to extend this to all the remaining Blighty films. But this is counterbalanced and augmented by the artist's film, War Memorial, which takes a much more distanced and critically 


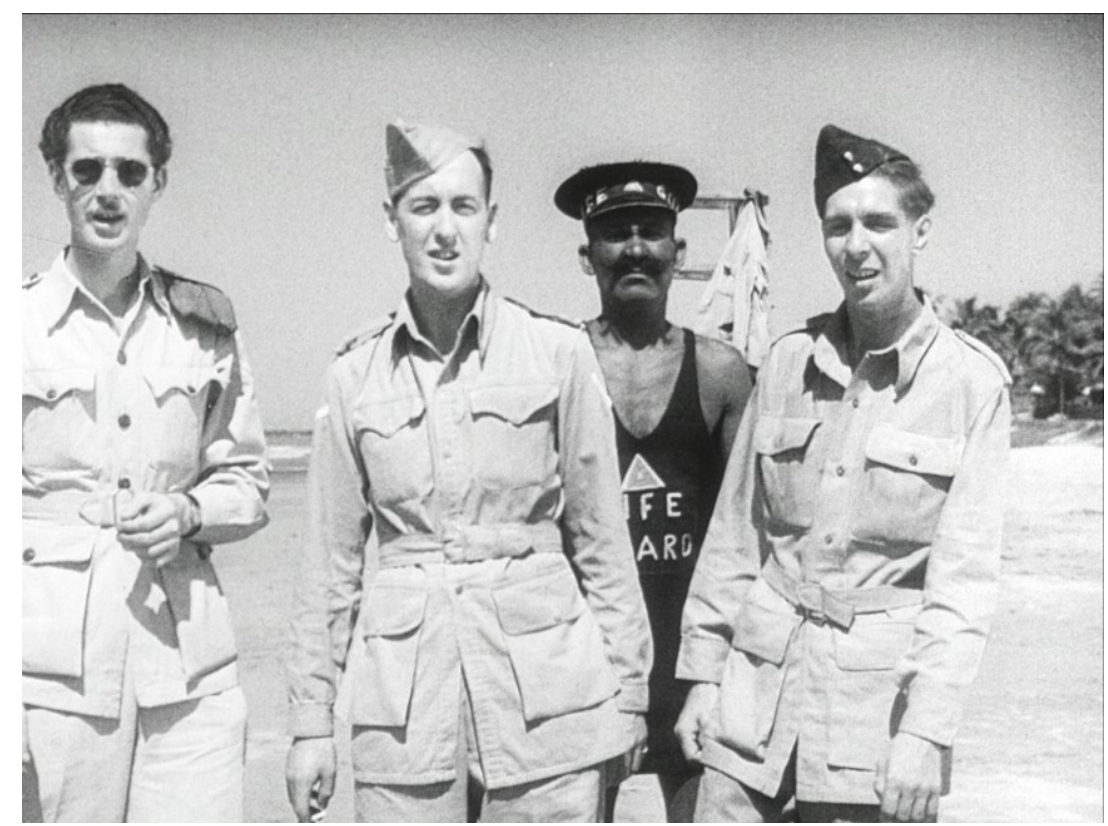

Figure1. "Anyone here from Sheffield?" (Calling Blighty 1944-6)

There has been much reflection and focus during the current centenary of World War One on remembrance, and in passing, on film as monument and commemoration. We question how we "remember, commemorate and represent suffering, courage and loss" (Frontline Club 2016) both of those men who fell in wartime but also those who survived into peace, but who then have almost all died in the intervening years. The Calling Blighty films are extraordinary, in that they are first person documents; the servicemen look directly into the camera and deliver messages in a naked and often openly emotional way. The feeling engendered is as if opening a secret letter from the past, where the author speaks not only to surviving relatives but also to ourselves, onlookers upon this distant war. Whilst the intention was to reassure and to bolster morale, many men betray their inner feelings, and give unselfconscious performances that reveal much around the edges about the war they were engaged in. And for the men delivering the messages these were live and immediate utterances, not looking back, and for their families viewing them, almost live.

The films are just one site where groups and individuals can negotiate their representation of war, and also of notions of the family. The entwining notions that wrap around their, and our, reception of these films are complex, mixing nostalgia, a yearning for a vanished world, the archetype of the heroic warrior, family memories, and national communal remembrance. In fact as part of the latter, I also made at the request of the British Embassy in Myanmar, a film that was shown as part of the Remembrance Day 2016 commemoration in Rangoon. This film opens (at their request) with images of the Taukkyan war cemetery in Rangoon, which contains over 6000 commonwealth burials from World War Two, then showed film clips of soldiers who had died in the war, delivering their messages in 1944, followed by close-ups of the inscriptions on their individual tombstones. The film was shown at a reception at 
the Ambassador's Residence on Remembrance Sunday to attendees from the British Legion, relatives of the fallen, and one living veteran of the war. Here the metaphorical connection between remembrance through a cemetery stone, and memorial through letters and films is made literal, but the issue of collective memory and war is given particularly sharp focus as these men were part of the Fourteenth, or as it was known, the "Forgotten" army.

These were men who perceived themselves as overlooked even on active service in wartime. As Mountbatten, then Far East commander, following General Slim's description, said , possibly apocryphally to troops in Burma in 1943, "I understand you believe you're the Forgotten Army. That's not true. The truth is nobody's ever bloody well heard of you" (ww2today.com 2016). One reason for this lacuna is that the Burma campaign had precious little in it to celebrate for a population in Britain until the victories over the Japanese at Kohima and Imphal in March 1944 onwards. Prior to that, the dominant narrative was one of shame following the surrender in Singapore (the largest capitulation in British military history according to Churchill), failure against the Japanese in jungle warfare (with the possible exception of the Chindit incursions behind Japanese lines), and persistent sickness as the overwhelming cause of casualties: 84 per cent of the Indian Army in 1943 fell victim to malaria, and there were 200 sickness cases for every battle casualty (McLynn 2011: 182). It is interesting to note that very few commercial feature films have been made about the $14^{\text {th }}$ Army of the Burma campaign, and that those few that can be loosely grouped as dealing with this theme are concerned with failure and compromise. The Bridge over the River Kwai (1957) and King Rat (1965), for example or the Camp on Blood Island (1958), are about Allied prisoners of war, and Yesterday's Enemy (1959) is reportedly based on a war crime perpetrated by a British army captain in Burma. The Hasty Heart (1949) which starred Ronald Reagan, is about disease and death in a jungle military hospital.

It was partly this sense of invisibility and the lack of morale it engendered which led to the making of the Calling Blighty films. The CKS (Combined Kinematograph Services film production and training centre) in India shot 391 ten minute films between January 1944 and 1946, of British soldiers in India and South East Asia Command, grouping men together from particular towns or cities, so that their families could be assembled in local cinemas to see greetings from their menfolk.

The distances were so great to India, Burma, and Malaya, that home leave was nigh on impossible, unlike in the European theatre, and welfare amenities were few and far between; NAAFI clubs, wireless sets, cinemas and ENSA visits were extremely rare or non-existent. Food was monotonous and compared poorly to US troops in the same conflict. The Americans had tinned beer, Coca-Cola and ice cream, whereas the British soldiers existed often on tins of bully beef and a strict beer ration of three bottles a month ("the monthly insult") (Sargent 1992).

All of this reinforced a sense of isolation, with a slow postal service in India which delayed letters to and from home, and led to the Directorate of Army Welfare conceiving of more direct messages to families, by radio and particularly film. Over 
the two years they were made, around 8000 servicemen and a handful of women were filmed either in India or on active service in Burma, Malaya and Singapore, and the results shown in local cinemas such as the Regent Cinema in Sheffield, or the Regal Twins on the Oxford Road Manchester. Of the films shot, a remarkable 64 still survive, and although these were not hidden, they were dispersed across film archives in the UK, and were little known of, nor had they been publicly screened. Paul Sargent had written the definitive account of their making for the Imperial War Museum in 1992 however the films themselves were largely unseen.

I came across one film in the Wessex film archive, of Southampton men speaking directly to camera, and was struck by the astonishingly direct address and the moving messages delivered by men speaking openly about their feelings for their families and wives far away. I mentioned this to Marion Hewitt the director of the North West Film Archive, and she revealed that they held 26 of the Manchester films, which had been found in the original film canisters in the basement of the Manchester Town Hall a quarter of a century previously, and we immediately decided to develop a project to find the families of the men in the films, and recreate the screenings.

Our aim was to find new ways of publicising the holdings and work of the film archive, but it was only later after talking to the many relatives of the men in the films (and two of the servicemen still alive), and then the first emotional public screening at HOME, Manchester's contemporary art centre, that we realised we were enacting a ritual of remembrance, and one with extraordinary power. An appearance on Radio 4 to try and trace more relatives of the men in the films led to an approach by television production company Oxford Scientific Films, who were then commissioned by Channel 4 to make a TV programme based around our project. The TV documentary, broadcast in June 2016, got wide media attention and popular critical approval, but took the stories of individual soldiers into a different realm of remembrance.

Millward (2000) says that "affluence has helped to turn identity into a commodity to be consumed," and the TV programme, in a sympathetic yet populist way, tapped into the Who Do You Think You Are genre of revealing personal identity by tracing ancestors, in the context of popular history. Both the screening/ritual events and the TV treatment located family stories in a bigger, more universal context of the war, and tapped into deep wells of personal emotion in the families and the viewer, but the viewpoint was largely and arguably necessarily uncritical. The men were depicted as forgotten heroes from a forgotten war: they spoke from beyond the grave, and their voices and stories which had been buried, could now be heard. Jay Winter has written of a "memory boom" (2006: 1) in the latter part of the twentieth century, and these representations fitted securely in this genre, where "history and memory are braided together in the public domain" (2006: 6). But the films themselves throw up all sorts of other implications that I wanted to explore in a creative and critical context, and which led to a 30 minute experimental documentary film called War Memorial (Hawley 2016). This makes much freer use of the images and sounds in the original films, to explore attitudes to the war, the 
multinational army, the conditions, and the realities of the conflict the men were engaged in, which they necessarily hid when delivering reassurance to their far distant families.

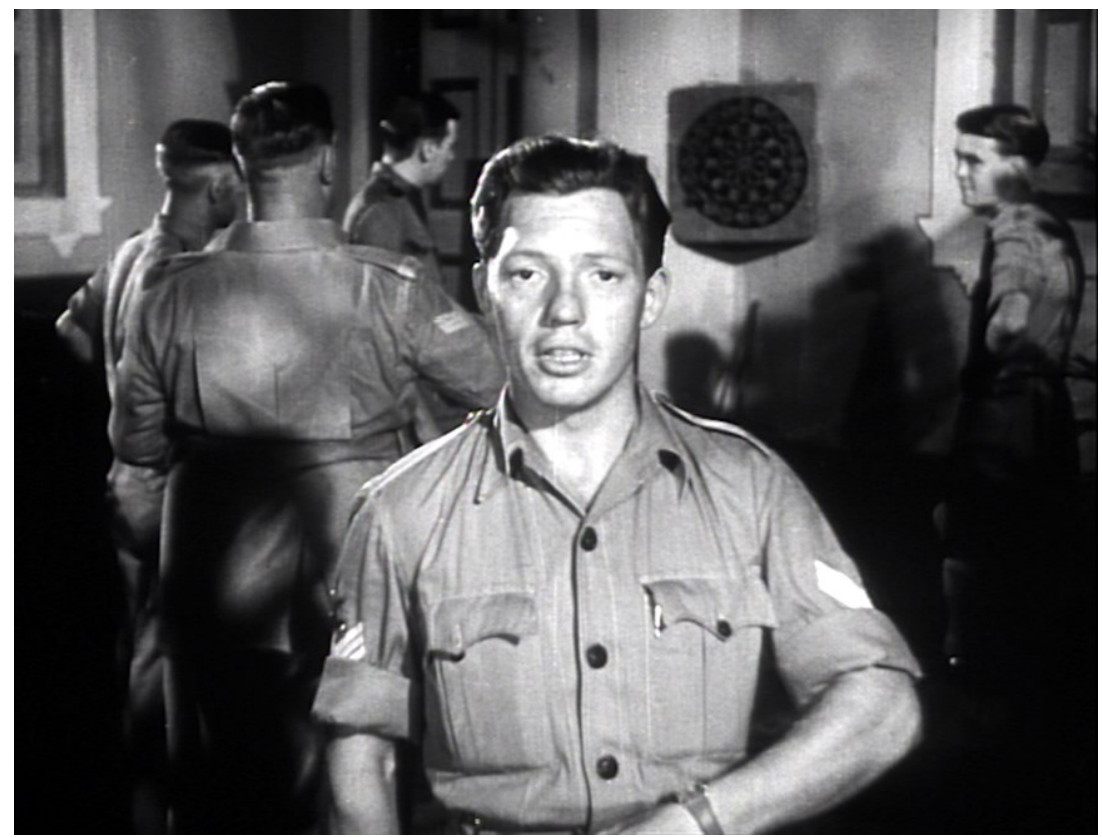

Figure 2. Sgt. Lawrence Yarwood (Calling Blighty 1944-6)

The Calling Blighty films were essentially filmed letters home, or in their brevity, often more like talking postcards. But despite this, they reveal much more about the men, their circumstances, their state of mind and the subtext of the war they were engaged in, than the simple format ostensibly offered. There was a typical pattern of message, where a man would greet his hometown and relatives, say that he was doing fine, getting his mail regularly (or not), and then say goodbye and handover to the next man. Hence Lawrence Yarwood's introduction by the previous soldier and message to his family in Sheffield; "Now Mrs Yarwood here's a surprise for you". "Hello Joan darling, how are you keeping? Well I hope. And you Winsome" (his five year old daughter, who also came to the screening 73 years later), "you were quite a little girl when I left you. Possibly not recognise your Pop; still I hope you're keeping well. Hello Mum and Dad, and Jean. Mail is coming through quite well; I'd like a lot more though. Well cheerio for now" (Calling Blighty 86 1944).

Lawrence was speaking from what appeared to be a NAAFI canteen in India, with men sitting at tables drinking tea or beer, often wreathed in clouds of smoke, and attended by Indian servants, and others playing cards or darts. In fact the canteen was an elaborate film set at the Shree sound studios in Bombay, where men were gathered together from widely distant parts of India or Burma, sometimes from different regiments but always from the same city or area (Sargent 1992: 29). Each man would normally walk up to the camera and address it/us the audience directly and then introduce the next man. They were not given specific instructions, but told to talk to their families and keep it fairly brief; they nearly all stopped after 30 seconds or so. There was no overt censorship, but the men would have known what was possible and not possible to say publicly from guidance given towards their 
written letters. In one a man talking to his family regrets that he doesn't write enough because" what I want to write probably wouldn't be passed by the censor". The films were lightly edited before they were sent to the UK, and in one case a man obviously swearing because he has forgotten what to say, has his words muted.

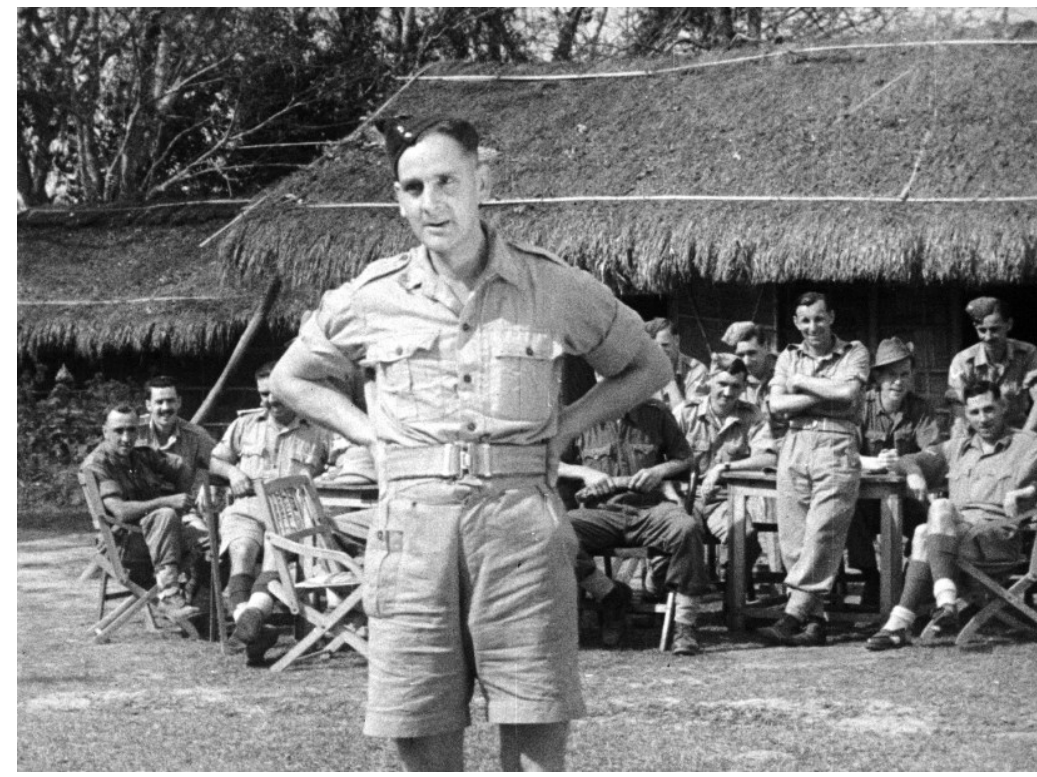

Figure 3. "Hope Jack's got his ticket and soon the bloody war's over". (Calling Blighty 1944-6)

But there was another kind of film, shot on location by mobile newsreel trucks with portable filming equipment, which followed the men to camps and locations in the theatre of war. These filming expeditions could be lengthy and potentially dangerous-one is recorded that travelled from Burma to Malaya to Singapore in a single tour (Sargent 1992: 29). Here the messages were similar but the paraphernalia of war is more difficult to elide, and in one film of York men somewhere in Burma, explosions can be heard, seemingly unnoticed by the men speaking to the camera (Calling Blighty 16 1944). The location films also presented opportunities for creative treatment by the largely unknown directors of the films, and there are many examples of rather forced dramatic scenarios which act as a prologue to the men who then turn to the audience to deliver their messages. A card game in the NAAFI where forced conversation is interrupted as the men face the camera to deliver their messages, or a football match where the soldiers pause to talk to the audience.

The films were meant to project normality and reassurance, and for the reels shot in Bombay, the men almost appear to be on holiday. Several sequences show men running out of the Arabian Sea in their swimming costumes, or sitting incongruously by a golf course. Most of the films end with the men waving goodbye and singing a song together, usually something relevant to their hometown such as she's a Lassie from Lancashire for the Manchester films, or Ilkla Moor Baht 'At for the York and South Yorkshire men. But there were other popular songs of the time, such as We'll Meet Again, and in the Shree Studios, often a vigorous piano tune by "Harry", who sometimes also played behind the men as they spoke. 
The codes of emotional expression in the films are distinctive, and mostly formal. Many men express their message as they would in a conventional letter "Hoping you are keeping well, as you see it leaves me well". Others are much more conversational or even comic. "Remember, Tojo can't beat a man who's served his time on t'corporation bus". "Ee but I could do with a Manchester cup of tea". Or a man to his wife Lillian, "Getting decent grub but I miss the old fish and chips and a pint now and again you know. Anyway keep the bed warm till I come home and we'll get up them stairs". But most of the men project an understated matter-of-factness - "I'm alright you know" - a stoicism occasionally belied by a open emotion which might be found unusual today, but seems remarkable for the period. "Lift up your heart bright eyes, be in God's keeping", one man says, his voice trembling, and several messages seem to come nakedly from the heart - "Look after Mary for me, because my love for her will never die, and I am looking forward to the day when we will once again be united". But extraordinary circumstances are also glossed over. "I'd better say a few words now that I'm here, it was six years ago we last spoke you remember?". "It was only this week I heard the sad news of mother's passing". "Well Gillian, here's your daddy, who you don't know, but who's looking to that day when he can see you, and tell you that he loves you".

Many of the men referenced the unusual event of their appearance on a cinema screen. "Hello my dear, this is me, not Clark Gable or Mickey Mouse". This was after all the golden age of cinema, just five years after the release of Gone With the Wind, in an era when to see oneself on any screen was an extreme rarity. In fact the newsreel sound film developed during the two years the films were being made, and represented a highly advanced technology for the day. To start with the films (always shot on the cinema release format of $35 \mathrm{~mm}$ instead of the amateur $16 \mathrm{~mm}$, which led to their high filmic quality even now), had originally a sync soundtrack recorded on a separate film recorder. This later gave way to a sound on film process, which made location filming much easier, however the full film apparatus with production lighting still filled up two location trucks. The crews were making four films a week, and after processing and editing in Bombay, they were dispatched by sea to Britain, which normally took six weeks, so that the whole process from shooting to screening in local cinemas took at least two to three months minimum.

When the films were eventually screened in regional cinemas, they were often crowded, with families, parents and children, up to 700 at a single screening, and they were sometimes repeated for a fresh audience (Sargent 1992: 29). Contemporary newspaper reports show that these were highly charged events. "Laughter and tears merged as mothers, wives, brothers, sisters, sweethearts and children saw 36 Bradford men who have been in India $31 / 2$ years appeared before them one by one, talking, smiling, and betraying the emotion they tried to hide by some familiar mannerism of hands or head" the News Chronicle reported in February 1944 of a Blighty screening at the New Victoria cinema Bradford, the first to be exhibited in the provinces" (News Chronicle 1944). The Bradford Telegraph and Argus said that "many wives' and mother's eyes were dimmed with happy tears" and "from the audience came exclamations of 'there he is, there's Daddy"' (Telegraph and Argus 1944) This was often the first time in years 
that families got to see their husbands or sons in the flesh, as some had been away on active service in the Far East for up to six years, and there were occasions when a man had been reported missing or killed in action between the making of the film and its screening. Because of the difficulty of editing the completed films, they were usually screened anyway to the grieving relatives (Sargent 1992: 30).

Much of the power of the films comes from the presentation in the first person in crisp $35 \mathrm{~mm}$ film images and exceptional sound, looking straight into the camera, a cinematic expression that was then, and still remains unusual. They have the immediacy of Skype, but with the high production values of cinema. This kind of direct address is almost unknown in fiction film, and rare in documentary, although we have become used to it through television, a medium almost unknown in Britain at that time, and interviewees on film are still usually told not to look directly at the camera. This intensity of gaze combined with the heightened "secular service" of the atmosphere surrounding the screenings combined to produce highly charged events.

There was another reason for the strangeness and directness of the films, in that the authentic working-class voice was almost unheard in the 1940s on film, and indeed did not become accepted in cinema until the kitchen sink films of the late 50s. The largely upper-middle-class documentary filmmakers of the left in the 1930s wanted to depict the working class as noble and heroic, but they did not allow them to express themselves in an unscripted way. Edgar Anstey's (and Ruby Grierson's) Housing Problems (1935) was the first documentary in which working-class voices, of East End men and women could be heard, but they appear stilted, or to be following a script. The men of the Calling Blighty films speak within a prescribed format but spontaneously, in their original accents, possibly for the first time ever in British film. It was the case also that the Northern and especially the Lancastrian voice was seen up until the 40 s and beyond as something essentially comic, as exemplified by George Formby, Jimmy Clitheroe, and Frank Randle. The men speaking in their Rochdale or Salford accents are presented in a warm but serious context, which adds to their authenticity and immediacy to the viewer today. Within the frame of the Blighty film and the censorship of wartime, they represent themselves, and these are self portraits rather than highly mediated representations through the often patronising filter of pre-and post war non-fiction film. 


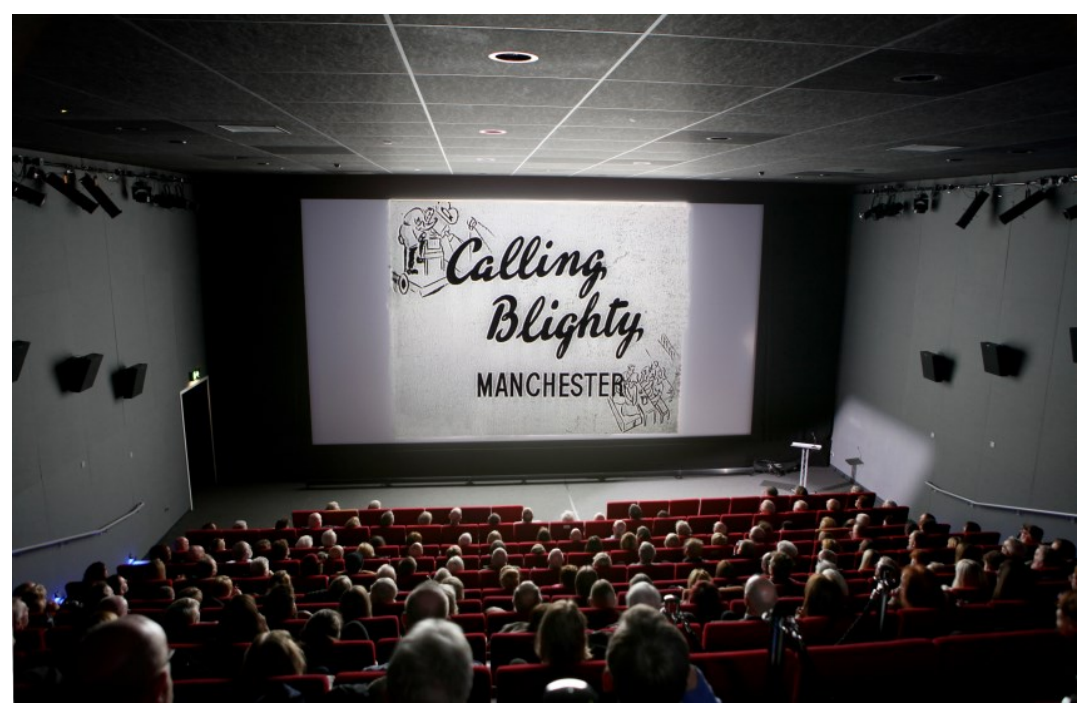

Figure 4. HOME, Manchester screening Nov 2015

In November 2015 I held with the North West Film Archive a recreated screening of the Manchester Blighty films to an audience of relatives, who we had traced through a large-scale publicity campaign. This screening was also filmed for the soon to be screened Channel 4 documentary. Held at HOME, Manchester's contemporary arts centre, the format had coincidentally many of the elements of the original screenings. After a film of the home front in Manchester in 1942, and an edited compilation which showed a variety of responses in the Blighty films, from humorous to deeply moving, a clip of each serviceman was shown with a short identifying title to a packed cinema of 250 relatives. We were also able to introduce two of the men still alive who appeared in the films to each other, Frank Risby and Ken Chadwick. In the Bradford screening the families had been "guests of the Northern command welfare officer" (News Chronicle 1944). In the HOME screening we had a short talk by Col Glover from the Queen's Lancashire Regiment Museum. There was a closing filmed song of Lassie from Lancashire which the audience joined in with, and then a drinks reception where the families could share at length stories of their wartime relatives (unknown to us at the time this closely resembled our recreated screenings seventy years later). In the Bradford cinema in 1944 "Afterwards over tea and sandwiches, officers who have seen Indian service described life at places where their men are serving" (News Chronicle 1944).

The relatives from several generations that we had traced reacted with great warmth and emotion, even when they had already seen their ancestor's films, sometimes several times. Clearly the ritual event was tapping into something that fused private and family memory, and public remembrance. It was also clear through anecdotal evidence that the straightforward process of reverential remembrance was sometimes clouded by complex family narratives. In one instance, we were told by the daughter of a man in the film that her brother who had been estranged from their late father, had been able to reconcile his relationship with him by seeing the film, just before the brother himself had died. In another, not in Manchester, a son who had been traced through a wide radio and newspaper search seemed remarkably cool about seeing the film of his father, who he had called out to as a young child in 1944 according to a contemporary report, when he had seen him in 
the cinema. He revealed that in fact he had been more or less abandoned by his lorry driver father, and brought up by his grandparents. The healing process of reunion and memory did not always operate straightforwardly, or at all.

One common thread was repeated to us again and again in talking to relatives. The men in the films, when they returned home, did not talk about their experiences in the war. Sometimes men had opened up to curious children or grandchildren before they died, but for most, their wartime experiences remained unmentioned and hidden. This was one of the background features of the Channel 4 documentary produced by Oxford scientific films, Messages Home, Lost Films of the British Army (Channel 4 2016). The narrative trope of treasures lost and rediscovered, and secrets revealed was explored in the programme which was whilst historically accurate, inevitably in the context of broadcast programming also highly geared to story-led television.

The program was in the Channel 4 Secret History strand, and followed five individual men, one, Ken Chadwick, still alive, and their families, and through their stories tried to open up the narrative of the war in the Far East, and interweave family stories with military history. The stories were framed by military historian, Rob Lyman and a voice-over by Paul McGann. There had been a suggestion of a female voice-over, perhaps Maxine Peake who had worked on a previous North West Film Archive production, however the Channel 4 editor had apparently responded that the audience would not accept a woman within the context of military history, a response also noted by Jay Winter when Judi Dench was one of the voices on the major TV series 1914-18: The Great War and the shaping of the Twentieth Century (Winter 2006:217).

To give first-hand testimony of the terrible conditions in Burma, a living ex-Chindit veteran Harold Shippey talked powerfully about jungle warfare and the impact on the men of disease and death. This trope of the horrors of war was both real and naturally emphasised within a dramatic approach to the conflict, but was not always the experience of the men involved. I interviewed Dennis Porter, Sheffield Burma veteran whose company had flushed the retreating Japanese out of villages in Burma in 1944, and who did not appear in the Blighty films, but his voice was included in a film made for a recreated Sheffield screening in order to set the context for local men who had been in the Fourteenth Army. He had only once fired his gun in anger, his only injuries came in training when his machine gun blew up on him, and of the long journeys across India in a cattle truck he said "I always enjoyed the travel". However the reality of disease and death was still very vivid to him (personal communication 2016).

The TV Messages Home focused on revelation. One story of Anne Alsop took her to the Burma grave of her father John Hartley, who had died action before she was born and who her mother after remarrying had erased from her life. When shown the film of her father for the first time in Manchester she showed relatively little emotion, but when asked to speak to her late father in front of his memorial in 
Rangoon, she became emotional and tearful, and the program overall emphasised loss and reconciliation. Alma, the daughter of Frank Miller, was shown his film as if for the first time whereupon she exclaimed and burst into tears. In fact she had seen the film several times before but always reacted with high emotion, and it was when we noticed this during the research phase in the Archive that we began to realise the extraordinary power of the films.

Another story focused on Norman Ellor, whose sons had a rich cache of letters to and from his then sweetheart, who later became his wife, and these gave a depth to the personal testimonial and allowed him to "speak" from the past to reveal his hatred of war, at odds to his ebullient greeting on the film. Here the letters as read by his son could uncover the actuality of his experience, which was hidden behind the need for reassurance he projected on screen.

Of the two veterans still alive of the 80 we had traced, Ken Chadwick, then 92, was interviewed in the art deco Stockport Plaza Cinema, as he saw film of himself in 1944, but his response was remarkably free from trauma and bitterness. "I look a bit fatter than I thought I was" was his chief reaction. The program was rigorous in quietly revealing if not emphasising the facts about the war in the Far East, that it was primarily to recapture colonies lost to the Japanese, that $85 \%$ of the Fourteenth Army came from the British Empire, mostly Indian but also Gurkhas from Nepal, East African regiments, Burmese and Burma hill tribesmen supported by Chinese and American allies (in fact the majority of battalions consisted of Indian troops led by British officers, and it was the Indian soldier who suffered the most casualties) (McLynn 2011:1). But the British had also suffered. One telling sequence group shot of Lancashire men in Burma in 1944 showed just how many of the men delivering confident messages had been killed by the end of the war.

The television programme, part of the Secret History series, focused on revelation: Frank Miller's children thought he had served in the catering Corps as a "cabbage mechanic", but the emblem on his uniform showed he was a member of the "legendary" Chindits. Frank Bramhall almost certainly suffered from PTSD for the rest of his life, undiagnosed, and almost unremarked upon. Of the huge reaction in the media to the programme and the space it occupied "between public remembrance and private memories" (Winter 2006: 206) the Radio Times perhaps came closest to identify the power of the Blighty films as filtered through the strictures of popular TV. "The messages from a distant warzone, spoken directly to loved ones, are extraordinary to watch, partly because some have Hollywoodquality cinematography applied to ordinary lads stumbling through endearments ("I trust you are all well... I'm in the pink" and so on), and partly because the soldiers are so unfeasibly cheerful, given the fighting they were going through" (Butcher 2016).

In addition to the recreated screenings, I also made an experimental artists' film, War Memorial (Hawley 2016), partly because I have for 35 years been an artist/filmmaker, and partly because there were profound elements in the Blighty films that had remained unexplored in the context of television and family. This was 
not a documentary, but a free and creative treatment of the images and sounds, rearranged in a way that was both as I hoped, respectful to the source material and what lay behind it, but also teased out some facets of the conflict and the men in a non-didactic way. K.L. Klein has talked about "memory as re-enchantment' (2000), and in some way whilst keeping the aesthetic dimension of these extraordinary films, War Memorial adds a critical edge. This war was essentially a masculine narrative, but some women do appear in the Calling Blighty films, and this was a dimension I wanted to bring out, along with references to death from the men themselves, and representation of the Commonwealth troops who despite being depicted (literally) in the background formed the vast majority of the combat troops of the Fourteenth Army.

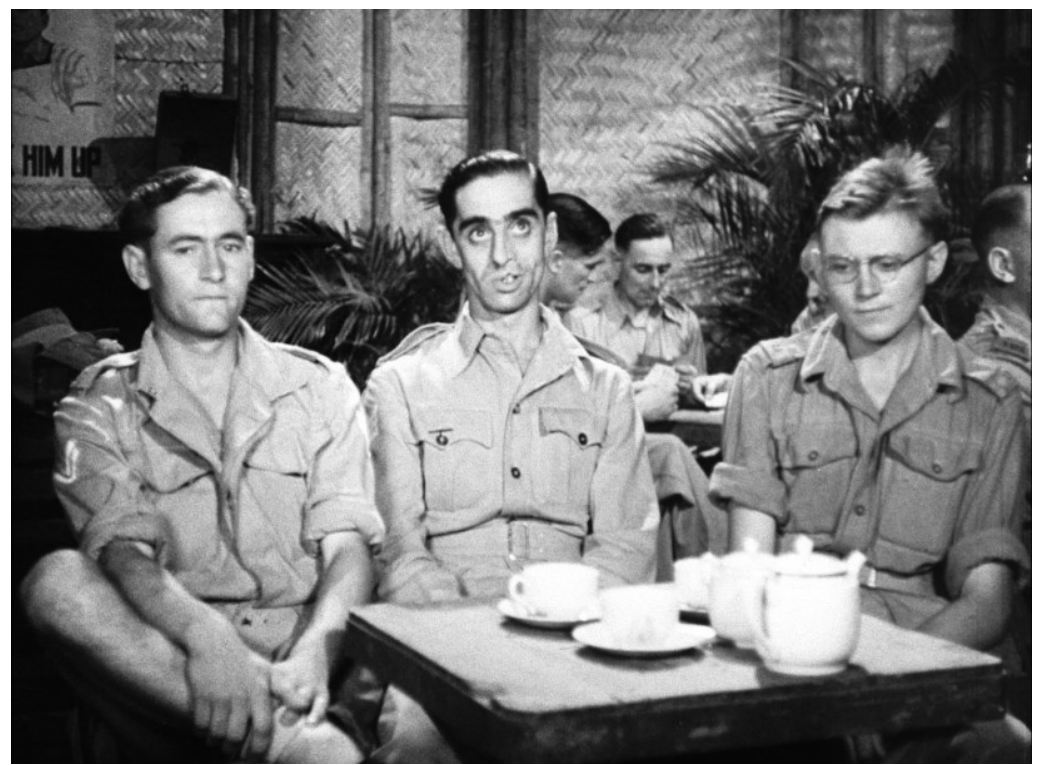

Figure 6. Still from War Memorial (Hawley 2016)

One issue, as the Radio Times pointed out, was the "unfeasibly cheerful" demeanour of the men. Where two men were shown in a shot but only one was speaking, I combined the unspeaking halves of the image to create long, almost still shots, where the two men appeared to be meditating or reflecting uncomfortably on their fate (image). This theme of introspection continues throughout the film, with individual men also cropped in the frame to exclude their companions, rare extended shots of men from this era not really doing anything, but their faces reflecting their thoughts.

Whilst the first ten minutes of War Memorial is almost silent, there is an intrusion into the film of the very voluble Flying Officer Timmins in Burma, who is unusual that with grim humour and in Lancashire dialect (he uses the word "gradely" meaning "excellent"), refers to the possibility of death. "This film comes to you by courtesy of the bully beef, beans, and browned off tea corporation, showing you some of Britain's bonny boys stationed in Burma. Of course folks you have seen Hedy Lamarr with Charles Boyer, you've seen Dorothy Lamour, in, and out of her sarong, you have seen Betty Grable with the twinkling legs, but you have seen nothing yet until you have seen the stars in the green battledress. Ee, it's a real 
gradely place, a real gradely place for anybody, to die in" (his companions laugh). And in the following shot marching paratroopers are seen singing Blood on the Risers, the traditional parachute regiment song to the tune of John Brown's Body. "Glory Glory what a hell of a way to die, and we ain't gonna jump no more". These are some of the few references to the very real risks of combat in the films (in fact almost 15,000 British troops died of injuries or disease in India and Burma (McLynn2011:1) although in a few sequences explosions and gunfire can be clearly heard.

A few soldiers also express less than positive sentiments: "I'm a bit browned off with this country". "There's some lovely places in India: of course this isn't one of them". Others hint of injuries, "I've got over my spell in dock", and sickness "I've lost a lot of weight but that's nothing to worry about". Some express deep emotion- "I miss you very much darling: keep smiling and remember I love you more than anything else in the world", whilst others try to project normality "Hello Nora darling, I'm fine as you can see", yet nonetheless betray this with a haunted appearance.

The relationship to the countries they were speaking from, and the multinational nature of the army they were fighting in is little explored overtly, but some contradictions are subtly revealed. The men use Hindi or Burmese words occasionally, especially "tikay" ("okay"), and "dekko"(look!"), and Blighty itself is originally a Hindi word. But Indians are without exception portrayed either as servants in the constructed NAAFI film set, or as silent extras within the shot. In one case an Indian lifeguard on Malabar Beach in Bombay follows a group of three Sheffield men, and stands mute behind them for some time whilst they deliver their messages.

In fact the Fourteenth Army was a multinational and Empire Army, where out of 690,000 men, over 600,000 were Commonweath forces, mostly Indian but also Burmese, Gurkhas, West African regiments, and Karen, as well as the 1200 US Allied forces and even in some battles 72000 Chinese soldiers (McLynn2011:1). Only 90,000 men of the army were British, but the contribution of the other nationalities is absent from the films.

In one particularly uncomfortable sequence, a West African regiment is portrayed in an obviously staged drama. An African soldier languidly carries a log to where a group of his comrades stand, whereupon a British Lance Corporal appears and starts to berate them in their own language, apparently for laziness. He is tapped on the shoulder by a British colleague and then turns to camera to deliver his message. In fact the East African troops, fighting for a part of the British Empire very far from their homeland, were widely regarded as excellent combatants (McLynn 2011:273) along with the fierce Gurkhas, and the Karen minority in Burma, as well as other Burmese hill tribes. In a later sequence, the West Africans are introduced by a British soldier dancing "an Ngoma, which we like very much", but they are portrayed half in battledress half in traditional costumes, a surreal and intentionally exotic incongruity in the Burmese jungle. 


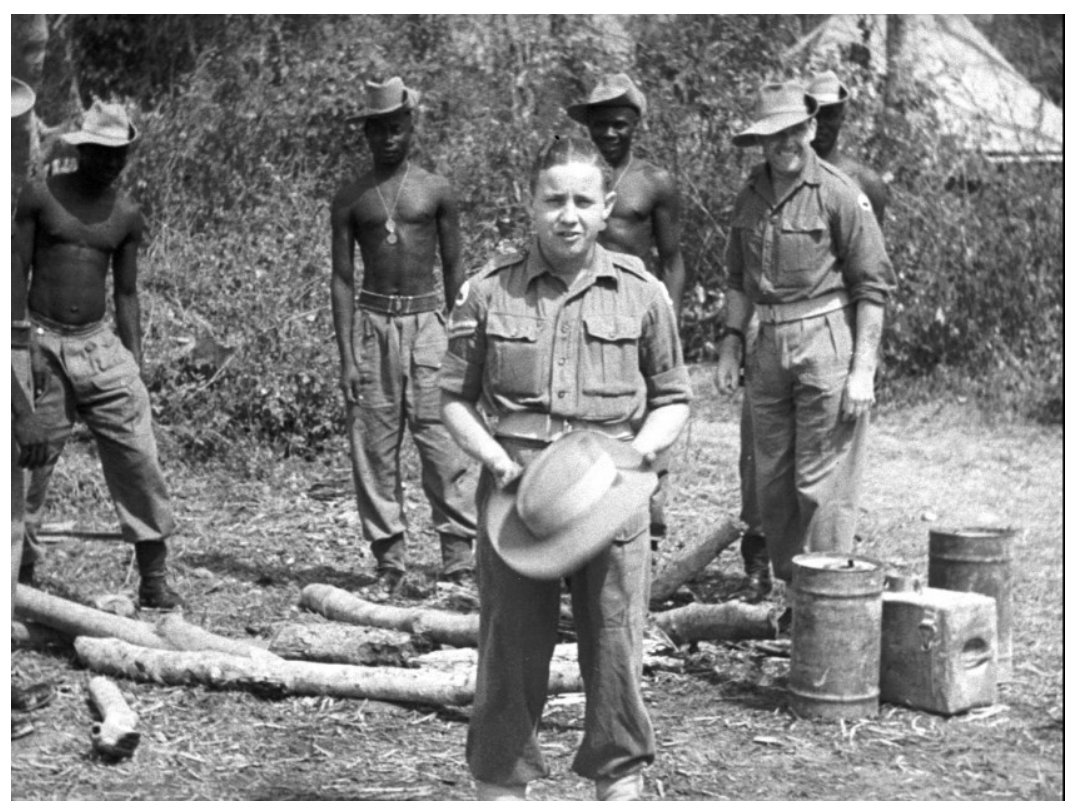

Figure 7. Still from War Memorial (Hawley 2016)

In most of the Calling Blighty films, the men step up one by one to the camera, deliver a message, and then introduce the next man who replaces them. But in some interesting sequences, the unknown directors try and employ film language to mask the disjuncture between an objective camera shot and first person message direct to camera. So in one film a lorry is stuck in the sand on Malabar Beach, as a group of men try to free it, and when a disembodied voice asks what they are doing, one responds that they are "looking for this calling Blighty business". The voice tells them they have found it, whereupon the men address the camera one by one to speak their messages to Sheffield. There are several variations on the theme of a man writing a letter home with pen and paper, who is told either offscreen or by another soldier beside him, "Why not speak to your family directly?". In another a group of men arrive rather late to the studio to be told by a senior officer that the filming is over. However he changes his mind, says bring on the mic (which appears on camera held by a soldier) and the messages are delivered. These quasi-fictional introductions sit awkwardly as framing devices within the direct Skype like address, but they reveal an interesting dimension of service life for the men, and I included some sequences in War Memorial, as well as some other messages delivered by women, who were a relative rarity serving in the Far East. Of the 600 or so messages I had access to, only four were from women.

\section{Conclusion}

"Time is the longest distance between two places" Tennessee Williams wrote in the Glass Menagerie (1945: 68) .The Calling Blighty films shrink time, because of their cinematic quality, the direct address to camera of the men and women, and their guileless self-presentation, often revealing deep feeling behind their wartime reserve. If war brings together personal family history and greater global history then the Blighty films are balanced between these two poles, with profound significance for the relatives of the service personnel depicted, but also rich with meaning about the hidden war they were engaged in. The Far East theatre for Britain 
was tinged with shame after the fall of Singapore and the loss of Burma, and the films partly aimed to improve the morale of the Forgotten Army, at least the British part of it, and the public on the Home Front. The contemporary screenings of the remaining films have had in recent times complex effects on family memories, public remembrance, the representation of the authentic Northern voice on screen, and how masculinity was portrayed in wartime.

The ongoing Calling Blighty project has engaged the subject of remembrance in three ways. One is in the recreations of the original screenings for relatives, a communal but also highly personal experience akin to a ritual or family service. As Jeanette Winterson says, we can talk to the dead, and we can also share our family experiences through seeing fathers and grandfathers on-screen (many families brought up to 20 relatives of all generations to see the films in Manchester and Sheffield).

The second, unforeseen by us, was the popular media memorial, a TV programme that engaged with the contradictions of the war but focussed mainly on five personal narratives. The heroic warrior myth was not confounded but in some ways reinforced-the cook turned out to be in fact a Chindit, and the Chindits were themselves mythologised. However the broadcast did engage with collective remembrance in public recollection through these personal stories, and gained wide and deserved popular acclaim.

The third was the critical and creative reinterpretation of the films, through a 30 minute experimental film. There is a difference between archive as monument, historical illustration with strong memory value, and the archive as document, an object to be critically questioned (Buchman and Mussou 2015). War Memorial the film treats the source Blighty films as document, to be critically examined, but also engages with and draws out their aesthetic and surreal qualities. The piece is not a didactic documentary but approaches, in intention at least, the quality of art.

All these three approaches are in some sense memorials, just as monuments, cemeteries, days of remembrance and unique ceremonies are, and they embody stories- narratives which are socially framed. The Calling Blighty project has engaged with multiple family and public narratives, and will continue to do so with the eventual ambition to locate on at one site on the web all of the men in the remaining films as a permanent resource for relatives to trace, and view their ancestors in the Fourteenth Army. Perhaps that site, and the echoes of the stories told by the relatives who have visited it and seen the films, has already become itself a memorial.

\section{Bibliography/filmography}

Anon (1944). India brought to Bradford. Wives, mothers see their loved ones. Telegraph and Argus, p.3

Buchman, M. and Mussou, C. (2015) Editorial View Vol 4 Issue 8 p.1 
Butcher,D. (2016). Messages Home: Lost Films of the British Army. Radio Times, $\left(25^{\text {th }}\right.$ June), p56.

Calling Blighty No 16 (1944). [film] India/Burma: CKS

Calling Blighty Sheffield No 86 (1944). [film] India/Burma: CKS

Calling Blighty. (1944-46). [series of 391 films] India/Burma: Combined Kinematograph Services

Frontline Club. 2016. Memory of War. [ONLINE] Available at:

http://www.frontlineclub.com/when-war-is-over-photography-and-the-memory-ofwar/. [Accessed 7 November 2016].

Housing Problems. (1935). [film] London: Edgar Anstey

King Rat. (1965). [film] Hollywood: Bryan Forbes

Klein, K.L. (2000), On the emergence of memory in historical discourse;

Representations, 69 (Winter), p. 127

McLynn, F. (2011). The Burma Campaign Disaster into Triumph 1942-5. London: Vintage.

Messages Home: Lost Films of the British Army, (2016). [TV programme]: Channel 4. Milward, A., "Bad Memories", The Times Literary Supplement 14 April 2000 p.8

Our special correspondent (1944). Army talkie 'brings back' soldiers to their families. News Chronicle, p.3

Oxford English Dictionary. (2017). In: 1st ed. Available at:

http://www.oed.com.ezproxy.mmu.ac.uk [Accessed 21 Jun. 2016]

Sargent, Paul (1992), "'Keep Smiling. Keep those chins up and God bless': filmed messages home from service personnel in the Far East during the Second World War." Imperial War Museum Review No. 7.

The Bridge over the River Kwai. (1957). [film] Hollywood: David Lean

The Camp on Blood Island. (1958). [film] London: Val Guest

The Hasty Heart. (1949). [film] Hollywood: Vincent Sherman

War Memorial. (2016). [video] Sheffield: Steve Hawley 
Williams, T. (1945) The Glass Menagerie. Acting Edition. New York: Dramatists Play Service Inc

Winter, J.M., 2006. Remembering war: The Great War between memory and history in the twentieth century. Yale: Yale University Press.

Winterson, J., 2012 Why be happy when you could be normal? London: Vintage.

Ww2today.com, (2016). Britain's Longest campaign of Word War 2 - Burma. [online] Available at: http://ww2today.com/featured/burma-britains-longest-campaign-ofworld-war-ii [Accessed 20 Apr. 2016].

Yesterday's Enemy. (1959). [film] London: Val Guest 